\title{
SOCIAL COHESION AND TRUST IN LOCAL COMMUNITIES IN HUNGARY
}

\author{
BÉLA JANKY \\ Hungarian Academy of Sciences, Institute for Sociology \\ Budapest University of Technology and Economics, Department of Sociology \\ and Communication \\ E-mail: janky.bela@tk.mta.hu
}

\begin{abstract}
This paper summarizes the first results of the analysis of a questionnaire survey on the determinants of social cohesion and interethnic relations in Hungarian local communities. The survey was carried out in villages and small towns in four different regions of the country in 2012. Our results show that the socioeconomic status and geo-cultural background of the local community significantly shape social cohesion and interethnic trust. Migration rate, on the other hand, plays a surprisingly minor role in shaping trust and cohesion. The effect of fractionalization is moderate, and, interestingly, mainly positive if national minorities are present in the local community.
\end{abstract}

Keywords: social capital, Hungary, trust, community survey, ethnic heterogeneity, migration

\section{Introduction}

This paper provides a summary of the first results of the analysis of a questionnaire survey on the determinants of social cohesion and interethnic relations in Hungarian local communities. The survey was carried out in villages and small towns in four different regions of the country in 2012.

We addressed in the first place the roles of the settlement status, geo-cultural background, ethnic fractionalization and migration rate in shaping social cohesion, interethnic trust and political preferences.

The points of departure of our analysis were Putnam's $(1995,2007)$ and Alesina and La Ferrara's (2002) seminal studies on local social capital and trust (see also Hooghe et al. 2009). Nonetheless, we concentrated on the slightly different concept of social cohesion (Chan et al. 2006, Letki 2008). Our special focus is on the effects of migration (c.f. Hickman et al. 2012), the socio-economic status 
of the community residents, and ethnic fractionalization on social cohesion and interethnic trust (c.f. Letki 2008, Stolle et al. 2008, Lawrence 2011).

Our results point to social status and geo-cultural background as major factors behind social cohesion and interethnic trust. Migration rate plays a surprisingly minor role in shaping trust and cohesion. The effect of fractionalization depends on the ethnic composition of the community. A large share of low status roma residents seem to decrease perceptions of social cohesion, while the presence of indigeneous national minorities may enhance community cohesion. The former result may reflect measurement problems stemming from the still uncovered mechanisms of status dependent ethnic fluidity. The latter point to the long run benefits of interethnic contact - in line with the so-called contact hypothesis. This latter finding seems to be in contrast with earlier findings at the first sight. We argue, however, that it may reflect some measurement problems on the one hand, but important substantive mechanisms on the other.

\section{Diversity and Cohesion}

The principle of embracing all kinds of diversity is considered by many of us as a key element of the cultural setup of the Euroatlantic civilization in the $21^{\text {st }}$ century. At the same time, however, there is an ongoing discussion in the academic sphere and the political arena alike about the supposed negative externalities of diversity. In particular, ethnic heterogeneity is in the spotlight in many countries.

In Western Europe, the public discourse on interethnic relations is centered around the (lack of) sociocultural integration of the first and second generations of economic immigrants. In the US, on the other hand, immigration is considered as a primarily economic issue. When it comes to interethnic tensions, the long shadow of Southern slavery has still remained the major problem. In Hungary, and in some other countries in Central-Eastern Europe, the Roma are in the focus of public debates on the effects of ethnic diversity.

Note also, however, that the issue of immigration has also been part of the Hungarian national political agenda in recent years. The topic was always raised as primarily an economic problem (similarly to the situation in the US), but some politicians were eager to refer to the supposed interethnic tensions in Western Europe and quote Western politicians talking about the problems of multiculturalism.

The scholarly interest in diversity and social cohesion had preceded the recent waves of public debates on the issue. Some of the most influental research programs were launched early on in the nineties. In his seminal work, Putnam (1995) warned of the potential negative effects of increasing geographical mobility on local social capital in the US. Nevertheless, ethnic diversity was not at the focus 
of his research. At the same time, some economists started to investigate the effects of ethnic diversity at the local and national level (e.g. Alesina and La Ferrara 2002). A consensus seemed to emerge about the negative effects of heterogeneity around this time. In his seminal paper, which was based on a large-scale survey on local communities, Putnam (2007) concluded that diversity could also erode intraethnic trust - along with the interethnic one.

All those results have seemed to be in sharp contrast with a long tradition in social psychological research, which have strongly influenced public discussions and policy in postwar Europe and America. Contact theory, as it is called, is traced back to Allport's (1954) conjectures about the effects of personal contacts between diverse people. It is assumed in this framework that personal experiences and stereotypes organize our understanding of the social world around us. A common observation is that differences attract more negative stereotypes than positive ones, introducing a negative bias in judging people whose gender, race, ethnicity, etc. differ from our own ones. Thus, interpersonal contacts between individuals of different ethnicity tend to improve interethnic relations, as there is an opportunity for the personal experience to overwrite biased stereotypes.

Contact theory has shaped public debates about school segregation from the 1950s, and has had a substantial influence on schooling policies all around the developed world. The decline of industrial capitalism in North America, and the emergence of inner city ghettos in North-Eastern metropolitan areas fostered the academic discussion about residential segregation from the late 1980s. Postindustrial transformation also raised concerns about the potential negative externalities of public housing policies in Western Europe. Namely, when the first waves of 'guest workers' and postcolonial immigrants arrived in large masses, new housing developments tended to concentrate immigrants in segregated neighborhoods. The fear came along with industrial decline that segregated neighborhoods would nurture alienated minority communities, a hostile majority public and recurring problems of cultural and economic integration.

Eventually, anti-segregationalist public discourse started to shape public housing policies in some European countries. Some efforts also were made at local and federal levels in the United States. Uncontrolled crime and studies on innercity ghettos may both have influenced the Clinton administration, when they initiated the demolishon of large metropolitan housing projects with particularly bad reputation.

In Hungary, segregation as a problem appeared in the academic discourse on public education few years after the fall of the communist regime. The major issue was the education a integration of Romani students. To a lesser degree, residential segregation also attracted some scholarly attention. As in some other countries in Central-Eastern Europe, segregated minority communities are concentrated in rural areas - instead of metropolitan neighborhoods. Some minor 
policy measures were taken against school segregation in the first decade of the $21^{\text {st }}$ century. On the other hand, no governmental efforts have been made to cope with residential segregation.

As the principle of residental desegregation had gained ground in housing policies, evidence had been accumulating on the negative externalities of mixing people of different culture and ethnicity. This was not a clash between theory and evidence, however. Theories were developed early on in sociology, psychology and economics about the difficulties of interethnic relations in heterogeneous communities.

Limits of contact theory have been emphasized by psychologists themselves. Minimal group experiments provide evidence supporting identity theory (Tajfel and Turner 1979), according which human beings are extremly sensitive to ingroup-outgroup frameworks. Economists also assume that ethnic preferences are not only initial dispositions but durable motivations which favor ingroup members over outgroup members. Blalock (1967) developed the conflict theory, which has become popular among sociologists. Conflict theory predicts that newcomers or other outgroup members in a community/society are often considered as persons who pose a threat to ingroup members' social and economic status. Often, all theories predicting enduring conflicts between various ethnic groups in local communities are grouped into the category of conflict theory.

Note that the theories of conflict and contact are not necessarily mutually exclusive. Conflict theories are about the effects of heterogeneity in itself. Contact theory, on the other hand, predicts the consequences of face-to-face peaceful interactions. The question still remains, however, that in real-world local communities, which types of mechanisms dominate the interethnic relations.

A large part of the evidence accumulated in the past 15 years indicates that conflict theories are better at explaining the accumulating evidence on the lonks between diversity and social cohesion (Van der Meer and Tolsma 2014).

However, some recent findings have challenged the above consensus about the negative impacts of heterogeneity. The most notable analysis can be found in the Sturgis et al. (2014) study which looks at London neighborhoods. By investigating very small administative units along with larger ones in a large and very colorful city, they tried to separate the partial effects of district heterogeneity and everyday contacts. Their results show that heterogeneity could be harmful for social cohesion but real mixing is beneficial - at least when one appropriately controls for neighborhood status as well.

Unfortunately, Hungarian scholars of urban studies have mostly ignored this issue. At least, large-scale comprehensive studies are still missing. It could be a problem for policy planning since evidence in the Western world indicates that the effect of diversity on local communities could largely be context dependent (e.g. Koopmans and Schaeffer 2014). The sociocultural landscape in Hun- 
gary differs in many ways from the ones in Western Europe and North America. Among the particularities one can find the large weight (and diversity) of national minority groups and the large number of ethnic Hungarian immigrants. The status of and challenges faced by the Roma communities are often compared to the ones of African-Americans and the muslim immigrants to Western Europe. However, the Roma differ in many ways from the above groups. They share the languague and the Christian sociocultural traditions with the majority population. Moreover, the Roma are much harder to be seen as a distinct racial group like the African-Anmericans. In our view, their stigmatization is less to do with cultural differences and more about the stigma of poverty - unlike in the case of muslim immigrants and African-Americans.

Our aim is to launch the quantitative empirical study on diversity and cohesion in the Hungarian context. This survey could be considered as a pilot study but we still think that it provides some useful evidence.

\section{Data and Methods}

Sampling. We conducted a computer-assisted telephone interviewing (CATI) survey in December 2012. The fieldwork was carried out by a professional polling firm, H-Reports Ltd. We have a stratified quota sample of 2,800 respondents.

The sampling design does not address any kind of 'representativity' - a major issue in large scale social surveys. Instead, it aims at increasing variances along the crucial dimensions we focus on. This is because we concentrate on causal analyses instead of providing a descriptive review on the level of social capital in local communities in Hungary.

Large enough variance of the independent variables is a must in multivariate analysis. However, some types of differences might rather inhibit to get a clear picture of certain causal mechanisms, instead of helping it. Namely, local communities are to be defined in a strikingly different way in small towns, middlesize cities, and large metropolitan areas. The major difficulty here is how to fit available community level data to the highly varying and sometimes fairly 'fuzzy' boundaries of real-word communities - those which affect individuals' daily life and social well-being. Financial constrains forced us to restrict our analysis to the relatively simpler cases, namely, communities of small towns and not very small rural areas where the ego-networks comprised of the crucial family ties, neighbors, friends and colleagues are predominantly attached to a well-defined administrative unit. In those communities, one can relatively easily detect those demographic characteristics which may affect local residents' social well-being and attitudes outside their narrow ego-networks. Spatially structured census, electoral, etc. datasets provide such information on those community level attributes. 
It is harder to capture the social world which matters for residents of large metropolitan areas. The major difficulty is with the search for appropriate spatial units which capture the boundaries of individual residents' social universes. Research on social capital should not, and, actually, does not restrain from the task of coping with this difficulty. In our project, however, we narrowed our focus on the easier cases due to the given constrains. That is, our survey is restricted to Hungarian towns of the size of 500-50,000 residents.

Our major concern is about the effects of immigration (and emigration) and inter-ethnic relations. However, the distribution of migration-rate among local communities is highly skewed in Hungary, with the large majority of towns experiencing only small-scale changes in their population in the past years. Therefore, we stratified the sample so as to over-represent the administrative units with high migration rate. The situation is similar to ethnic fractionalization, and we also artificially increased the variance in ethnic composition. To detect the differences between distressed and affluent communities, we increased the variance in status (as measured by employment rate and average educational level). Survey responses provide evidence on inter-ethnic relations though, we used data on the results of the recent parliamentary elections to increase variance in this dimension as well. Namely, we adopted the local electoral performance of the major far right party (named Jobbik) as a proxy for inter-ethnic tensions in the community. Jobbik has not been a one-issue party, but undoubtedly put the 'Roma-issue' at the very center of its electoral campaign in 2010.

Administrative units could be sufficiently good proxies for the social universes of a large share of local residents. Nonetheless, indicators based solely on those units cannot fully grasp the socio-cultural patterns and economic perspectives which significantly frame how individuals perceive the social reality and how they intend to cope with the perceived challenges. Hungary is a small country with appr.10 million of inhabitants; and is often regarded as a culturally homogeneous society. In reality, regional economic differences are fairly large in international comparison in this country. Moreover there is a large body of historical, ethnographic and sociological literature on the significant regional differences in socio-cultural patterns along several dimensions of social life and individual attitudes and strategies. For instance, the social construction of the Roma minority shows very different patterns across various regions of the country. There is now a consensus that those differences cannot be fully understand simply by referring to current socio-economic and demographic conditions. To capture the impacts of the wider socio-cultural context we introduced regional strata as well. As in the case of the other contextual variables, we aimed at maximizing variance. Therefore, we concentrated on regions farther away from the average. We deliberately chose four counties (of the 19 ones, excluding the metropolitan area of Budapest) to capture differences in economic perspectives and cultural traditions. Two of them are among the most prosperous regions, while 
the other two experienced economic decline in the post-communist transition. Note that large parts of the latter counties had been somewhat less prosperous compared to other regions during the past two centuries of capitalist development. The share of the Roma population is above the average in both of the distressed counties. However, ethnographic evidence and some statistical data indicate relevant differences between the two regions in the socio-cultural patterns of interethnic relations.

To sum up, our sampling units were villages and towns (up to the size of 50,000 inhabitants) in the four counties mentioned above. Then, we created 36 categories based on socio-economic status (high-middle-low), immigration rate (high-low), share of Roma residents (high-middle-low), and finally, recent electoral performance of the major far right party (high-low). Cutting points of the 'high' and 'low' levels are at the $20^{\text {th }}$ and $80^{\text {th }}$ percentiles of the distributions (of the settlements considered in the four counties). The cutting points were shifted towards the $30^{\text {th }}$ and $70^{\text {th }}$ percentiles in case there were not enough settlements in a category. Altogether we selected 119 villages and towns into the sample. Quota instructions restricted the number of respondents in a settlement, moreover their distribution according to age and labor market status.

The questionnaire. The average length of the interviews was about 10 minutes. Our 'objective' indicators of local social capital rely on questions about the respondents' participation in local religious, sport or other entertainment events. We asked about the participation as an organizer and audience/consumer separately. We also checked the frequency of church attendance. Several items addressed the residents' perceptions of the local social capital. A block of questions focuses on visible signals of disorderly neighborhoods (presence of abandoned dogs, graffitis, teenage gangs and street drinkers). A more 'subjective' measure of local social capital addresses the respondents' opinions on indicators of social cohesion in their home town. This block of items includes questions about the friendliness of the neighborhood, the local residents' helpfulness, norm enforcement, and perceived level of trust. Indicators of generalized trust and subjective well-being were also added to the questionnaire.

We also attached settlement level data, mainly the sampling indicators to the individual records. These include settlement size, rate of educated residents, employment rate, share of ethnic minorities and major denominations. In the case of minorities we distinguished those belonging to the Roma community, and those who identify themselves with one of the (indigenous) national minority groups in Hungary.

Dependent variables. We investigated four aspects of local social environment: local civic activities, perception of social cohesion, interethnic trust, and, finally, the recent (2010) electoral performance of the anti-Roma far right party (Jobbik). Several questions addressed the respondent's local civic activities. Based on those items, we constructed a factor score, which was then used in the multi- 
variate model. We also constructed a factor score for indicating the respondent's perception of local social cohesion.

\section{Results}

Only a small part of the individual level variance in local civic activity can be explained by community level characteristics (Table 1). As one might expected, citizens are more likely to participate in local events in small settlements than in larger ones. Catholic and Lutheran communities seem to be the most mobilizing ones. As far as the individual characteristics are concerned, educated, married people with a job are those who participate in such events relatively more often. Older residents are more active than the younger ones (note that we included a selective list of local activities).

Our models explain subjective perception of local social cohesion much better than individuals' activities (Table 2). Level of social cohesion decreases with the share of the Roma in the settlement, but increases in the percentage of other minority groups. This latter one is an intriguing result which points to the special role those indigenous minority groups play in Central-Europe. Interestingly enough, residents of settlements with a large Greek Catholic community report the highest level of local social cohesion.

One should note that the local migration rate does not play any role in social cohesion. More precisely, the indicator of migration is not connected to our two indicators of local social cohesion. This is in sharp contrast with our expectations, and future research is needed to explore this finding in more detail.

Our third set of models addresses interethnic trust (Table 3). Namely, trust in Roma people. As we expected, there is a strong geo-cultural effect detected in our models. The estimates do not show any significant effects of the migration rate and the share of the Roma population. However, one should be cautious about those results. In our telephone survey, much fewer respondents identified themselves as Roma than expected. It is likely that many (probably most) of those who expressed their connection to the Roma community in the last census, refused to do so in the phone survey. This is a serious measurement problem we have to address in future analysis of the data.

Finally we tried to explain the election results of the outspokenly anti-Roma Jobbik party in the last general elections. Here we adopted the communities as the primary observation units. The model's explanatory power is very high, but is mainly due to the regional effect. We could not detect very strong settlementlevel explanatory indicators. Interestingly enough, there is no role for the share of the Roma in most of our models. Ethnically mixed communities (as far as the traditional "national" minorities are concerned), however, seem to be less prone to vote in large numbers for the far-right. 
Table 1 Determinants of active local citizenship. OLS linear regression estimates

\begin{tabular}{|c|c|c|c|c|c|}
\hline & (1) & (2) & (3) & (4) & (5) \\
\hline \multirow[t]{2}{*}{ population } & $-0.000308 * *$ & $-0.000316^{* *}$ & $-0.000316^{* *}$ & $-0.000368 * *$ & $-0.000368 * *$ \\
\hline & $(0.000135)$ & $(0.000136)$ & $(0.000150)$ & $(0.000144)$ & $(0.000148)$ \\
\hline \multirow[t]{2}{*}{ cmigrate } & -0.0688 & -0.0702 & -0.0702 & -0.0980 & -0.0980 \\
\hline & $(0.0704)$ & $(0.0708)$ & $(0.0615)$ & $(0.0671)$ & $(0.0622)$ \\
\hline \multirow[t]{2}{*}{ cedu } & 0.0345 & 0.0481 & 0.0481 & -0.0166 & -0.0166 \\
\hline & $(0.0674)$ & $(0.0677)$ & $(0.0663)$ & $(0.0797)$ & $(0.0722)$ \\
\hline \multirow[t]{2}{*}{ cactive } & 0.0810 & 0.0908 & 0.0908 & -0.00125 & -0.00125 \\
\hline & $(0.225)$ & $(0.223)$ & $(0.182)$ & $(0.261)$ & $(0.204)$ \\
\hline \multirow[t]{2}{*}{ croma } & 0.0328 & 0.0468 & 0.0468 & 0.0155 & 0.0155 \\
\hline & $(0.118)$ & $(0.118)$ & $(0.102)$ & $(0.114)$ & $(0.100)$ \\
\hline \multirow[t]{2}{*}{ cminority } & 0.0310 & 0.0285 & 0.0285 & 0.0451 & 0.0451 \\
\hline & $(0.0676)$ & $(0.0693)$ & $(0.0661)$ & $(0.0613)$ & $(0.0677)$ \\
\hline \multirow[t]{2}{*}{ ccatholic } & 0.113 & 0.100 & $0.100 * *$ & 0.108 & $0.108 * *$ \\
\hline & $(0.0751)$ & (0.0739) & $(0.0464)$ & $(0.0837)$ & (0.0499) \\
\hline \multirow[t]{2}{*}{ cgreek } & -0.0344 & -0.0511 & -0.0511 & 0.0623 & 0.0623 \\
\hline & $(0.132)$ & $(0.131)$ & $(0.127)$ & $(0.145)$ & $(0.133)$ \\
\hline \multirow[t]{2}{*}{ creform } & 0.0656 & 0.0549 & 0.0549 & 0.0969 & 0.0969 \\
\hline & (0.0988) & (0.0969) & $(0.0642)$ & $(0.115)$ & $(0.0723)$ \\
\hline \multirow[t]{2}{*}{ cluther } & $0.351 * * *$ & $0.325^{* * *}$ & $0.325^{* * *}$ & $0.284 * *$ & $0.284^{* * *}$ \\
\hline & $(0.100)$ & $(0.0996)$ & $(0.0987)$ & $(0.116)$ & $(0.103)$ \\
\hline \multirow[t]{2}{*}{ bornhere } & & $2.980 * *$ & $2.980 * *$ & $4.226 * * *$ & $4.226 * * *$ \\
\hline & & (1.223) & (1.229) & $(1.208)$ & $(1.243)$ \\
\hline \multirow[t]{2}{*}{ migrant2000 } & & 1.312 & 1.312 & 0.542 & 0.542 \\
\hline & & $(1.741)$ & $(1.752)$ & (1.802) & $(1.760)$ \\
\hline \multirow[t]{2}{*}{ kor } & & & & $0.0794 *$ & $0.0794 *$ \\
\hline & & & & $(0.0460)$ & $(0.0411)$ \\
\hline \multirow[t]{2}{*}{ male } & & & & -1.095 & -1.095 \\
\hline & & & & (1.304) & (1.209) \\
\hline \multirow[t]{2}{*}{ working } & & & & $6.089 * * *$ & $6.089 * * *$ \\
\hline & & & & $(1.420)$ & (1.289) \\
\hline \multirow[t]{2}{*}{ nohighschool } & & & & $-6.359 * * *$ & $-6.359 * * *$ \\
\hline & & & & (1.884) & (1.655) \\
\hline \multirow[t]{2}{*}{ degree } & & & & $7.338 * * *$ & $7.338 * * *$ \\
\hline & & & & $(1.429)$ & $(1.374)$ \\
\hline \multirow[t]{2}{*}{ partner } & & & & $6.770 * * *$ & $6.770 * * *$ \\
\hline & & & & $(1.122)$ & (1.189) \\
\hline \multirow[t]{2}{*}{ baranya } & & & & -2.310 & -2.310 \\
\hline & & & & $(2.784)$ & (2.616) \\
\hline \multirow[t]{2}{*}{ baz } & & & & -3.017 & -3.017 \\
\hline & & & & (2.958) & $(2.672)$ \\
\hline \multirow[t]{2}{*}{ pest } & & & & 0.396 & 0.396 \\
\hline & & & & (2.518) & (2.204) \\
\hline \multirow[t]{2}{*}{ Constant } & $26.21 * *$ & $24.45^{* *}$ & $24.45^{* * * *}$ & 18.88 & $18.88 * *$ \\
\hline & (10.30) & (10.26) & (7.058) & (13.38) & (9.256) \\
\hline Observations & 2,800 & 2,800 & 2,800 & 2,800 & 2,800 \\
\hline R-squared & 0.011 & 0.013 & 0.013 & 0.066 & 0.066 \\
\hline
\end{tabular}

Dependent variable: local activities factor score transformed to a 0-100 scale. Standard errors in parentheses. Cluster-robust standard errors are applied in (3) and (5) *** $\mathrm{p}<0.01, * * \mathrm{p}<0.05$, $* \mathrm{p}<0.1$ 
Table 2 Determinants of the perception of local social cohesion. OLS linear regression estimates

\begin{tabular}{|c|c|c|c|c|c|}
\hline & (1) & (2) & (3) & (4) & (5) \\
\hline population & $\begin{array}{c}-0.000453 * * * \\
(0.000139)\end{array}$ & $\begin{array}{c}-0.000431^{* * *} \\
(0.000135)\end{array}$ & $\begin{array}{c}-0.000431^{* * *} \\
(8.27 \mathrm{e}-05)\end{array}$ & $\begin{array}{c}-0.000408 * * * \\
(0.000137)\end{array}$ & $\begin{array}{c}-0.000408 * * * \\
(8.28 \mathrm{e}-05)\end{array}$ \\
\hline cmigrate & $\begin{array}{c}0.0455 \\
(0.0497)\end{array}$ & $\begin{array}{c}0.0491 \\
(0.0498)\end{array}$ & $\begin{array}{c}0.0491 \\
(0.0339)\end{array}$ & $\begin{array}{c}0.0495 \\
(0.0500)\end{array}$ & $\begin{array}{c}0.0495 \\
(0.0347)\end{array}$ \\
\hline cedu & $\begin{array}{c}0.0382 \\
(0.0535)\end{array}$ & $\begin{array}{c}0.0304 \\
(0.0527)\end{array}$ & $\begin{array}{c}0.0304 \\
(0.0366)\end{array}$ & $\begin{array}{c}0.0468 \\
(0.0592)\end{array}$ & $\begin{array}{c}0.0468 \\
(0.0403)\end{array}$ \\
\hline cactive & $\begin{array}{c}0.493^{* * *} \\
(0.142)\end{array}$ & $\begin{array}{c}0.485^{* * *} \\
(0.137)\end{array}$ & $\begin{array}{c}0.485^{* * *} \\
(0.101)\end{array}$ & $\begin{array}{c}0.468 * * * \\
(0.165)\end{array}$ & $\begin{array}{c}0.468 * * * \\
(0.114)\end{array}$ \\
\hline croma & $\begin{array}{c}-0.330 * * * \\
(0.116)\end{array}$ & $\begin{array}{c}-0.337 * * * \\
(0.113)\end{array}$ & $\begin{array}{c}-0.337 * * * \\
(0.0561)\end{array}$ & $\begin{array}{c}-0.336 * * * \\
(0.115)\end{array}$ & $\begin{array}{c}-0.336 * * * \\
(0.0558)\end{array}$ \\
\hline cminority & $\begin{array}{l}0.0813 * \\
(0.0420)\end{array}$ & $\begin{array}{l}0.0809 * \\
(0.0419)\end{array}$ & $\begin{array}{c}0.0809 * * \\
(0.0365)\end{array}$ & $\begin{array}{c}0.0861 * * \\
(0.0352)\end{array}$ & $\begin{array}{c}0.0861 * * \\
(0.0378)\end{array}$ \\
\hline ccatholic & $\begin{array}{c}0.0848 * * \\
(0.0368)\end{array}$ & $\begin{array}{c}0.0832 * * \\
(0.0344)\end{array}$ & $\begin{array}{c}0.0832 * * * \\
(0.0256)\end{array}$ & $\begin{array}{c}0.0517 \\
(0.0370)\end{array}$ & $\begin{array}{l}0.0517 * \\
(0.0278)\end{array}$ \\
\hline cgreek & $\begin{array}{c}0.406 * * * \\
(0.0691)\end{array}$ & $\begin{array}{c}0.414^{* * *} \\
(0.0699)\end{array}$ & $\begin{array}{c}0.414^{* * * *} \\
(0.0703)\end{array}$ & $\begin{array}{c}0.333^{* * * *} \\
(0.0691)\end{array}$ & $\begin{array}{c}0.333^{* * * *} \\
(0.0744)\end{array}$ \\
\hline creform & $\begin{array}{c}0.0591 \\
(0.0510)\end{array}$ & $\begin{array}{c}0.0596 \\
(0.0486)\end{array}$ & $\begin{array}{l}0.0596 * \\
(0.0355)\end{array}$ & $\begin{array}{c}0.0173 \\
(0.0550)\end{array}$ & $\begin{array}{c}0.0173 \\
(0.0403)\end{array}$ \\
\hline cluther & $\begin{array}{c}-0.00655 \\
(0.0976)\end{array}$ & $\begin{array}{l}-0.0167 \\
(0.0953)\end{array}$ & $\begin{array}{l}-0.0167 \\
(0.0546)\end{array}$ & $\begin{array}{l}-0.0355 \\
(0.0835)\end{array}$ & $\begin{array}{l}-0.0355 \\
(0.0573)\end{array}$ \\
\hline bornhere & & $\begin{array}{l}-1.076 \\
(0.704)\end{array}$ & $\begin{array}{l}-1.076 \\
(0.679)\end{array}$ & $\begin{array}{c}0.236 \\
(0.732)\end{array}$ & $\begin{array}{c}0.236 \\
(0.694)\end{array}$ \\
\hline migrant2000 & & $\begin{array}{l}-0.125 \\
(1.104)\end{array}$ & $\begin{array}{l}-0.125 \\
(0.967)\end{array}$ & $\begin{array}{c}1.650 \\
(1.098)\end{array}$ & $\begin{array}{l}1.650 * \\
(0.981)\end{array}$ \\
\hline objcap & & $\begin{array}{c}0.0574 * * * \\
(0.0108)\end{array}$ & $\begin{array}{c}0.0574 * * * \\
(0.0105)\end{array}$ & $\begin{array}{c}0.0625 * * * \\
(0.0117)\end{array}$ & $\begin{array}{c}0.0625^{* * *} \\
(0.0106)\end{array}$ \\
\hline kor & & & & $\begin{array}{c}0.166^{* * *} \\
(0.0271)\end{array}$ & $\begin{array}{c}0.166^{* * *} \\
(0.0229)\end{array}$ \\
\hline male & & & & $\begin{array}{l}-0.399 \\
(0.724)\end{array}$ & $\begin{array}{l}-0.399 \\
(0.674)\end{array}$ \\
\hline working & & & & $\begin{array}{l}0.0930 \\
(0.709)\end{array}$ & $\begin{array}{l}0.0930 \\
(0.721)\end{array}$ \\
\hline nohighschool & & & & $\begin{array}{l}1.816^{*} \\
(0.982)\end{array}$ & $\begin{array}{c}1.816^{* *} \\
(0.925)\end{array}$ \\
\hline degree & & & & $\begin{array}{c}2.076 * * * \\
(0.695)\end{array}$ & $\begin{array}{c}2.076 * * * \\
(0.770)\end{array}$ \\
\hline partner & & & & $\begin{array}{l}-1.094 \\
(0.761)\end{array}$ & $\begin{array}{l}-1.094 \\
(0.667)\end{array}$ \\
\hline baranya & & & & $\begin{array}{l}-1.090 \\
(2.208)\end{array}$ & $\begin{array}{l}-1.090 \\
(1.459)\end{array}$ \\
\hline baz & & & & $\begin{array}{l}-0.480 \\
(1.960)\end{array}$ & $\begin{array}{l}-0.480 \\
(1.490)\end{array}$ \\
\hline pest & & & & $\begin{array}{l}-2.522 \\
(1.721)\end{array}$ & $\begin{array}{c}-2.522 * * \\
(1.229)\end{array}$ \\
\hline Constant & $\begin{array}{c}43.90 * * * \\
(6.270)\end{array}$ & $\begin{array}{c}42.99 * * * \\
(6.055)\end{array}$ & $\begin{array}{c}42.99 * * * \\
(3.905)\end{array}$ & $\begin{array}{c}36.98 * * * \\
(7.784)\end{array}$ & $\begin{array}{c}36.98^{* * *} \\
(5.165)\end{array}$ \\
\hline Observations & 2,800 & 2,800 & 2,800 & 2,800 & 2,800 \\
\hline R-squared & 0.110 & 0.120 & 0.120 & 0.150 & 0.150 \\
\hline
\end{tabular}

Dependent variable: perception of local cohesion factor score transformed to a $0-100$ scale. Standard errors in parentheses. Cluster-robust standard errors are applied in (3) and (5) $* * * \mathrm{p}<0.01$, $* * \mathrm{p}<0.05, * \mathrm{p}<0.1$ 
Table 3 Determinants of the level of distrust in Roma people. OLS linear regression estimates

\begin{tabular}{|c|c|c|c|c|c|}
\hline & (1) & (2) & (3) & (4) & (5) \\
\hline \multirow{2}{*}{ population } & 4.19e-06 & 3.61e-06 & $3.61 \mathrm{e}-06$ & $3.85 e-06$ & $3.85 \mathrm{e}-06$ \\
\hline & $(3.90 \mathrm{e}-06)$ & (3.89e-06) & $(2.38 \mathrm{e}-06)$ & $(3.21 \mathrm{e}-06)$ & $(2.38 \mathrm{e}-06)$ \\
\hline \multirow[t]{2}{*}{ cmigrate } & -0.00117 & -0.00126 & -0.00126 & -0.000510 & -0.000510 \\
\hline & $(0.00121)$ & (0.00119) & (0.000962) & $(0.00126)$ & (0.000982) \\
\hline \multirow[t]{2}{*}{ cedu } & 0.00143 & 0.00163 & 0.00163 & 0.000468 & 0.000468 \\
\hline & $(0.00116)$ & (0.00117) & (0.00104) & $(0.00134)$ & $(0.00114)$ \\
\hline \multirow[t]{2}{*}{ cactive } & $-0.00705^{* *}$ & $-0.00687^{* *}$ & $-0.00687^{* *}$ & -0.00419 & -0.00419 \\
\hline & $(0.00321)$ & $(0.00317)$ & $(0.00285)$ & $(0.00347)$ & $(0.00321)$ \\
\hline \multirow[t]{2}{*}{ croma } & -0.00206 & -0.00184 & -0.00184 & -0.00243 & -0.00243 \\
\hline & $(0.00192)$ & (0.00188) & (0.00158) & (0.00149) & (0.00158) \\
\hline \multirow[t]{2}{*}{ cminority } & -0.00123 & -0.00122 & -0.00122 & 0.000639 & 0.000639 \\
\hline & (0.00338) & (0.00329) & (0.00115) & (0.00230) & $(0.00120)$ \\
\hline \multirow[t]{2}{*}{ ccatholic } & 0.000139 & 0.000160 & 0.000160 & -0.000546 & -0.000546 \\
\hline & (0.000768) & (0.000773) & $(0.000726)$ & $(0.000820)$ & $(0.000790)$ \\
\hline \multirow[t]{2}{*}{ cgreek } & 0.00261 & 0.00237 & 0.00237 & -0.00111 & -0.00111 \\
\hline & (0.00199) & $(0.00204)$ & $(0.00210)$ & $(0.00209)$ & $(0.00223)$ \\
\hline \multirow[t]{2}{*}{ creform } & 0.00144 & 0.00141 & 0.00141 & -0.00139 & -0.00139 \\
\hline & $(0.00113)$ & (0.00113) & $(0.00100)$ & (0.00129) & $(0.00114)$ \\
\hline \multirow[t]{2}{*}{ cluther } & 0.00346 & $0.00371^{*}$ & $0.00371^{* *}$ & $0.00361^{* *}$ & $0.00361^{* *}$ \\
\hline & $(0.00221)$ & $(0.00215)$ & $(0.00155)$ & (0.00177) & $(0.00163)$ \\
\hline \multirow[t]{2}{*}{ bornhere } & & 0.0250 & 0.0250 & -0.00950 & -0.00950 \\
\hline & & (0.0193) & (0.0193) & $(0.0191)$ & (0.0197) \\
\hline \multirow[t]{2}{*}{ migrant2000 } & & -0.00116 & -0.00116 & -0.0312 & -0.0312 \\
\hline & & $(0.0265)$ & $(0.0275)$ & $(0.0260)$ & (0.0278) \\
\hline \multirow[t]{2}{*}{ objcap } & & $-0.00141^{* * *}$ & $-0.00141^{* * *}$ & $-0.00128^{* * *}$ & $-0.00128^{* * *}$ \\
\hline & & $(0.000292)$ & $(0.000296)$ & $(0.000313)$ & $(0.000299)$ \\
\hline \multirow[t]{2}{*}{ kor } & & & & $-0.00328^{* * *}$ & $-0.00328^{* * *}$ \\
\hline & & & & $(0.000662)$ & $(0.000653)$ \\
\hline \multirow[t]{2}{*}{ male } & & & & 0.0185 & 0.0185 \\
\hline & & & & (0.0209) & (0.0191) \\
\hline \multirow[t]{2}{*}{ working } & & & & 0.00500 & 0.00500 \\
\hline & & & & (0.0199) & (0.0205) \\
\hline \multirow[t]{2}{*}{ nohighschool } & & & & 0.0189 & 0.0189 \\
\hline & & & & $(0.0250)$ & $(0.0262)$ \\
\hline \multirow[t]{2}{*}{ degree } & & & & $-0.121^{* * *}$ & $-0.121^{* * *}$ \\
\hline & & & & (0.0229) & $(0.0220)$ \\
\hline \multirow{2}{*}{ partner } & & & & 0.0322 & $0.0322 *$ \\
\hline & & & & $(0.0204)$ & $(0.0190)$ \\
\hline \multirow[t]{2}{*}{ baranya } & & & & -0.0464 & -0.0464 \\
\hline & & & & (0.0518) & $(0.0418)$ \\
\hline \multirow[t]{2}{*}{ baz } & & & & $0.169 * * *$ & $0.169 * * *$ \\
\hline & & & & $(0.0527)$ & $(0.0424)$ \\
\hline \multirow[t]{2}{*}{ pest } & & & & 0.0565 & 0.0565 \\
\hline & & & & (0.0385) & $(0.0347)$ \\
\hline Constant & $0.459 * * *$ & $0.484 * * *$ & $0.484^{* * *}$ & $0.592^{* * *}$ & $0.592^{* * *}$ \\
\hline & $(0.127)$ & $(0.124)$ & $(0.110)$ & $(0.146)$ & $(0.146)$ \\
\hline Observations & 2,647 & 2,647 & 2,647 & 2,647 & 2,647 \\
\hline R-squared & 0.011 & 0.020 & 0.020 & 0.056 & 0.056 \\
\hline
\end{tabular}

Standard errors in parentheses. Cluster-robust standard errors are applied in (3) and (5) $* * * \mathrm{p}<0.01$, $* * \mathrm{p}<0.05, * \mathrm{p}<0.1$ 
Table 4 Election results (\%) of Jobbik party in the last general election (2010)

\begin{tabular}{|c|c|c|c|c|c|}
\hline & (1) & (2) & (3) & (4) & (5) \\
\hline \multirow{2}{*}{ croma } & 0.00997 & -0.0418 & $-0.309 * * *$ & -0.0934 & -0.0589 \\
\hline & $(0.100)$ & $(0.114)$ & $(0.0807)$ & $(0.110)$ & (0.113) \\
\hline \multirow[t]{2}{*}{ objcap } & & -0.0965 & 0.0105 & -0.0359 & -0.0170 \\
\hline & & $(0.108)$ & $(0.0880)$ & $(0.0937)$ & $(0.0967)$ \\
\hline \multirow[t]{2}{*}{ subjcap } & & -0.107 & -0.149 & -0.137 & -0.105 \\
\hline & & (0.127) & (0.0928) & $(0.1000)$ & (0.103) \\
\hline \multirow[t]{2}{*}{ baranya_1 } & & & -0.428 & $3.737 * *$ & $4.161^{* *}$ \\
\hline & & & (1.348) & (1.728) & (1.713) \\
\hline \multirow[t]{2}{*}{ baz } & & & $16.36 * * *$ & $21.64 * * *$ & $20.34 * * *$ \\
\hline & & & (1.565) & $(1.950)$ & (2.104) \\
\hline \multirow[t]{2}{*}{ pest } & & & $4.049 * * *$ & $7.430 * * *$ & $6.941 * * *$ \\
\hline & & & $(1.448)$ & $(1.862)$ & $(1.857)$ \\
\hline \multirow[t]{2}{*}{ population } & & & & $-0.000223^{* *}$ & $-0.000232^{* *}$ \\
\hline & & & & (9.62e-05) & $(9.70 e-05)$ \\
\hline \multirow[t]{2}{*}{ cmigrate } & & & & -0.0398 & -0.0399 \\
\hline & & & & $(0.0491)$ & $(0.0486)$ \\
\hline \multirow[t]{2}{*}{ cedu } & & & & -0.0490 & -0.0383 \\
\hline & & & & $(0.0603)$ & (0.0589) \\
\hline \multirow[t]{2}{*}{ cactive } & & & & $0.509 * *$ & $0.512 * *$ \\
\hline & & & & $(0.203)$ & $(0.203)$ \\
\hline \multirow[t]{2}{*}{ cminority } & & & & $-0.101 *$ & $-0.117^{* *}$ \\
\hline & & & & $(0.0578)$ & $(0.0478)$ \\
\hline \multirow[t]{2}{*}{ ccatholic } & & & & -0.00267 & 0.00511 \\
\hline & & & & $(0.0521)$ & $(0.0524)$ \\
\hline \multirow[t]{2}{*}{ cgreek } & & & & -0.163 & -0.167 \\
\hline & & & & $(0.113)$ & (0.113) \\
\hline \multirow[t]{2}{*}{ creform } & & & & -0.0119 & 0.00218 \\
\hline & & & & $(0.0756)$ & $(0.0753)$ \\
\hline \multirow[t]{2}{*}{ cluther } & & & & $0.224 * *$ & $0.204^{* *}$ \\
\hline & & & & $(0.0933)$ & $(0.0943)$ \\
\hline \multirow[t]{2}{*}{ cignotrust } & & & & & $7.614^{*}$ \\
\hline & & & & & (4.489) \\
\hline \multirow[t]{2}{*}{ Constant } & $19.55^{* * *}$ & $30.49 * * *$ & $23.68 * * *$ & 4.188 & -1.306 \\
\hline & $(0.893)$ & $(8.660)$ & $(6.745)$ & (10.26) & (10.74) \\
\hline Observations & 119 & 119 & 119 & 119 & 119 \\
\hline R-squared & 0.000 & 0.018 & 0.588 & 0.672 & 0.681 \\
\hline
\end{tabular}

Population vote on the party list. Cluster-robust standard errors in parentheses. ${ }^{* * *} \mathrm{p}<0.01$, $* * \mathrm{p}<0.05, * \mathrm{p}<0.1$ 


\section{Conclusions}

Our non-representative community survey of Hungarian localities should be considered as a pilot study on local social capital in Hungary. Nonetheless, there are some important lessons to be learned from our preliminary results. First of all, patterns of local cohesion and trust seem to differ from those found in Western Europe and North America. Maybe the most important characteristic is the presence of national minorities, and the roles they play in fostering local social capital in Hungary. National minorities can be considered as special types of indigeneous ethnic groups, and the local impact of their presence clearly shows the potential long-run benefits of diversity. This is a kind of mechanism which is harder to detect in the present-day Western societal contexts. Note, however, that some recent analyses could capture this kinds of positive effects of diversity in the Western World as well (e.g. Sturgis et al. 2014).

When it comes to the Roma minority, the effect of local ethnic heterogeneity on trust seems to be negative - in line with many findings across the developed world. However, one should think about the possibility that there might be some inherent measurement problems related to Romani identity in Hungary. The social construction of the Roma is strongly built on social status in many countries in Europe. There has been a heated discussion about the situation in Hungary - still not settled fully. But there is a widespread suspicion among Hungarian scholars that the 'whitening' of high status Roma people, and the 'Gypsification' of the underclass makes it impossible to look at the Roma community as a fairly stable social group whose integration into the wider society can be measured by comparing the situations of the Roma populations at different time points. Until this measurement problem is not settled, one should take any results about Romarelated diversity with a pinch of salt.

Future research should include better measurement of neighborhoods - in line with recent international trends. That is, we should be able to separate interacting heterogeneous communities from segregated ones (c.f. Strugis et al. 2014). Moreover, international comparative studies could tell more about regional and country level characteristics of the formation of local social capital in Hungary. Finally, careful research design can account for the abovementioned effects of ethnic fluidity on the perceived influence of Roma-related heterogeneity on local trust and cohesion.

\section{Acknowledgements}

My research was supported by Hungarian Scientific Research Fund (OTKA) grants K 79150 and K 113208, and the MTA Bolyai Scholarship. I am grateful 
to Zsuzsanna Zsarkó and Barbara Marosváry for their assistance in data compilation, and the participants of the Conference at Bloomington for their valuable questions and comments.

\section{References}

Alesina, A. and La Ferrara, E., 2002. Who Trusts Others? Journal of Public Economics, 85(2), 207-234.

Allport, G., 1954. The Nature of Prejudice. Cambridge, MA: Addison-Wesley.

Blalock, H., 1967. Toward a Theory of Minority-group Relations. New York: Wiley and Sons.

Chan, J., To, H. P. and Chan, E., 2006. Reconsidering Social Cohesion: Developing a Definition and Analytical Framework for Empirical Research. Social Indicators Research, 75(2), 273-302.

Dassopoulos, A. and Monnat, S. M., 2011. Do Perceptions of Social Cohesion, Social Support, and Social Control Mediate the Effects of Local Community Participation on Neighborhood Satisfaction? Environment and Behavior, 43(4), 546-565.

Hickman, M. J., Mai, N. and Crowley, H., 2012. Migration and Social Cohesion in the UK. Palgrave Macmillan.

Hooghe, M., Reeskens, T., Stolle, D. and Trappers, A., 2009. Ethnic Diversity and Generalized Trust in Europe. A Cross-National Multilevel Study. Comparative Political Studies, 42(2), 198-223.

Koopmans, R. and Schaeffer, M., 2014. Perceptions of Ethno-Cultural Diversity and Neighborhood Cohesion in Three European Countries (No. SP VI 2014-103). WZB Discussion Paper.

Lawrence, J., 2011. The Effect of Ethnic Diversity and Community Disadvantage on Social Cohesion: A Multi-Level Analysis of Social Capital and Interethnic Relations in UK Communities. European Sociological Review, 27(1), 70-89.

Letki, N., 2008. Does Diversity Erode Social Cohesion? Social Capital and Race in British Neighbourhoods. Political Studies, 56(1), 99-126.

Putnam, R. D., 1995. Bowling Alone: America’s Declining Social Capital. Journal of Democracy, 6(1), 65-78.

Putnam, R. D., 2007. E pluribus unum: Diversity and Community in the Twenty-First Century. The 2006 Johan Skytte Prize Lecture. Scandinavian Political Studies, 30(2), 137-174.

Stolle, D., Soroka, S. and Johnston, R., 2008. When does diversity erode trust? Neighborhood diversity, interpersonal trust and the mediating effect of social interactions. Political Studies, 56(1), 57-75.

Sturgis, P., Brunton-Smith, I., Kuha, J. and Jackson, J., 2014. Ethnic Diversity, Segregation and the Social Cohesion of Neighbourhoods in London. Ethnic and Racial Studies, 37(8), 1286-1309.

Tajfel, H., and Turner, J. C., 1979. An Integrative Theory of Intergroup Conflict. In Austin, W. G., \& Worchel, S. (Eds.). The social psychology of intergroup relations, Monterey, CA: Brooks/ Cole., pp. 33-47.

Uslaner, E., 2010. Trust, Diversity, and Segregation in the United States and the United Kingdom. Comparative Sociology 10 (4): 415-434.

Van der Meer, T. and Tolsma, J., 2014. Ethnic Diversity and Its Supposed Detrimental Effects on Social Cohesion. Annual Review of Sociology (40). 